\title{
Recent changes in the diet and survival of Atlantic puffin chicks in the face of climate change and commercial fishing in midcoast Maine, USA
}

\author{
Stephen W. Kress ${ }^{a \star}$, Paula Shannon ${ }^{\mathrm{b}}$, and Christopher O’Neal ${ }^{\mathrm{c}}$ \\ ${ }^{a}$ National Audubon Society Seabird Restoration Program, 159 Sapsucker Woods Road, Ithaca, NY 14850, \\ USA, ' National Audubon Society Seabird Restoration Program, 12 Audubon Road, Bremen, Maine \\ 04551, 'Synovus, 1490 Distribution Drive, Suwanee, GA 30024, USA \\ *skress@audubon.org
}

\begin{abstract}
We examined the diet of Atlantic puffin (Fratercula arctica) chicks at three midcoast Maine, USA, colonies during the years 2005-2014 and found that the puffins at each island have a distinct diet that has changed in recent years. White hake (Urophycis tenuis) is by far the most frequently delivered prey at each island. Atlantic herring (Clupea harengus) is the second most frequently delivered food, but has declined in recent years on two islands. In contrast, butterfish (Poronotus triacanthus), haddock (Melanogrammus aeglefinus), and redfish (Sebastes spp.) have increased in the puffin diet on all islands. Chick condition declined significantly from 1993 to 2009. We demonstrate that puffin chicks with greater body weight experience a higher chance of postfledging survival as compared to chicks with lower body weight. The years 2012-2013 were a period of extreme sea surface warming, in which puffin hatching success and productivity sharply declined. This study provides new insight into changes in marine communities, examining changes in chick diet. We discuss our findings in relation to warming sea surface temperatures, recent climate-related decline in puffin productivity in the Gulf of Maine, and the impact of commercial fisheries on forage fish.
\end{abstract}

Key words: Atlantic puffin, puffin chick diet, forage fish, climate change, commercial fishing

Editor: Steven Cooke

Received: December 05, 2015

Accepted: February 29, 2016

Published: April 21, 2016

Copyright: (c) 2016 Kress et al. This work is licensed under a Creative Commons Attribution 4.0 International License (CC BY 4.0), which permits unrestricted use, distribution, and reproduction in any medium, provided the original author(s) and source are credited.

Competing interests: The author(s) have declared that no competing interests exist.

\section{Introduction}

Puffins are especially good indicators of forage fish populations because of their strong breeding site fidelity and extended chick-rearing period. Although young puffins usually prospect at multiple nesting islands in the years prior to their first nesting (Kress and Nettleship 1988), once they select a nesting island, they will continue to nest at their selected home, with some living beyond 40 years (Harris and Wanless 2012). As the normal fledging age for puffins is 38-44 days and puffins forage for their chicks within about $20 \mathrm{~km}$ of their nesting colony (Harris and Wanless 2012), an individual pair feeds their chick from the waters near the colony for about 6 weeks. Since puffins nesting at the same island are not completely synchronized, the colony as a whole continues feeding from nearby waters for more than 2 months from the beginning of the hatch until the last chick fledges. A puffin colony is therefore similar to a community-based fishery, fishing near home, sampling nearby waters, and 
vulnerable to local conditions that influence the abundance of forage fish, including localized depletion due to human competitors.

Puffins nesting in midcoast Maine are especially vulnerable to changes in ocean warming as they are nesting at the southern limit of the species range and are thus most vulnerable to variation in water temperature and other climate change mechanisms. Many studies point to the importance of including predatory fish, marine mammals, and seabirds in models predicting forage fish populations (Cury et al. 2011; Tyrell et al. 2011; Smith et al. 2015). These models provide theoretical justification for including the effects of predators when designing ecosystem-based fishery management plans (Fogarty 2014; Travis et al. 2014; Overholtz et al. 2008), but empirical studies that examine the relationship between ample food, condition of seabird chicks, and chick survival in the wild are rare.

Previous studies have shown that the growth and survival of puffin chicks is influenced by the abundance of food in their ecosystems (Barrett and Rikardsen 1992; Barrett 2002; Eilertsen et al. 2008). This study further supports this connection by demonstrating a link between chick condition and postfledging survival of puffin chicks.

Atlantic puffins feed on small forage fish that are usually less than $10 \mathrm{~cm}$ long. In the Gulf of Maine, puffins may forage at different depths. However, according to Spencer (2012), the average dive depth of puffins was less than $15 \mathrm{~m}$ at one colony, whereas at another colony dive depth ranged from 15 to $70 \mathrm{~m}$, averaging $19.61 \pm 14 \mathrm{~m}$ (S. Symons, personal communication, 2016). Burger and Simpson (1986) found that in Newfoundland, puffins may dive as deep as $68 \mathrm{~m}$ to obtain food for young chicks. There is scarcity of reliable data about the distance that parent puffins travel to obtain food for chicks. Moreover, Spencer (2012) found that puffins from Petit Manan Island in the Gulf of Maine travel an average of $31 \mathrm{~km}$ from their nesting island to obtain food for their young, and a Scottish study found that most puffins forage within $20 \mathrm{~km}$ of their nesting colonies (Harris and Wanless 2012). Puffins at Machias Seal Island on the US/Canadian border travel an average of $44 \mathrm{~km}$ from their nesting island to feed (S. Symons, personal communication, 2016).

A program to restore Maine puffin populations has resulted in an increase of more than 1000 pairs of puffins since the 1980s, but warmer water, changes in primary productivity, and increased pressure from fisheries on forage fish are new threats to puffins at the southern edge of their North American range.

Although puffin productivity in the Gulf of Maine is entwined with both changes in climate and the impact of fisheries, it is important to attempt to disentangle the impacts of climate from those of commercial fisheries upon forage fish. Intense fishing pressure reduces the abundance of forage fish populations and truncates their age structure, leading to range contractions or shifts (Bell et al. 2014; Overholtz 2002). For wildlife such as puffins to survive, fisheries managers need to set management goals that include ample meals for them (Cury et al. 2011; Skern-Mauritzen et al. 2015).

Ecosystem-based fisheries management must also give consideration to local prey abundance and density, as these factors relate to foraging efficiency by puffins and other birds around nesting colonies. Protecting key foraging areas is as important as protecting nesting islands. Such specific inputs can help set system-wide reference points, along with appropriate fishing constraints, to protect individual species and habitats (Fogarty 2014). This is particularly important considering that the principal fish in the puffins' diet will likely shift further north toward cooler water (Nye et al. 2009), and puffins and other marine animals that depend on small forage fish will adapt to new species that move into the Gulf of Maine from further south, or to species better managed by fisheries to provide ample biomass for wildlife. 


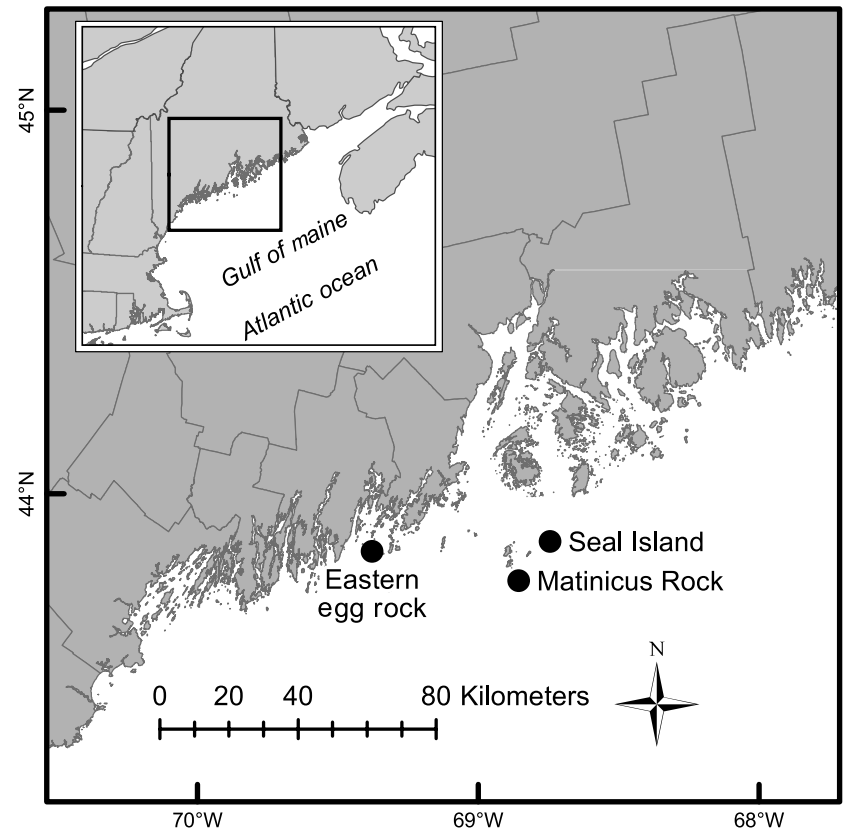

Fig. 1. Study sites. Map courtesy of Robert Houston, USFWS.

\section{Methods}

\section{Study sites}

We present data regarding puffin productivity, chick diet, chick condition, and postfledging survival at three Maine colonies (Fig. 1). One of these, Matinicus Rock, is a relic population, surviving since the feather-hunting days of the late 19th century when most Maine puffin colonies were extirpated due to hunting (Drury 1973). The other two sites, Eastern Egg Rock and Seal Island National Wildlife Refuge, are restored colonies (Jones and Kress 2012). All three colonies are managed by the National Audubon Society, and puffins at all three colonies nest under large granite boulders.

Eastern Egg Rock $\left(43^{\circ} 52^{\prime} \mathrm{N}, 69^{\circ} 22^{\prime} \mathrm{W}\right)$ is a 2.9 ha treeless island located in the mouth of Muscongus Bay off midcoast Maine, USA, approximately $9 \mathrm{~km}$ from the nearest mainland. The island consists of a central meadow surrounded by a perimeter of granite boulders. Its highest ground is only $7 \mathrm{~m}$ above the sea level. An estimated 150 pairs of Atlantic puffins nested here in 2015.

Matinicus Rock $\left(43^{\circ} 47^{\prime} \mathrm{N}, 68^{\circ} 51^{\prime} \mathrm{W}\right)$ is a 7 ha treeless island with a 3 ha central meadow overlying a shallow peat soil with outcropping granitic ridges. It is located approximately $32 \mathrm{~km}$ from the mainland in the outer Penobscot Bay. By 2015, over 400 puffin pairs were estimated to be nesting on the island.

Seal Island National Wildlife Refuge $\left(43^{\circ} 53^{\prime} \mathrm{N}, 68^{\circ} 44^{\prime} \mathrm{W}\right)$ is a 40 ha treeless island located about $14 \mathrm{~km}$ northeast of Matinicus Rock, $32 \mathrm{~km}$ from the mainland in the outer Penobscot Bay. The colony had about 500 puffin pairs in 2015.

\section{Diet changes}

We examined the prey items delivered to puffin chicks at three midcoast Maine puffin colonies (Eastern Egg Rock, Matinicus Rock, and Seal Island National Wildlife Refuge) over the years 
2005-2014 to determine if the diets were similar at the three islands. Observers trained in fish identification recorded observations with binoculars and/or cameras from $1 \times 1 \mathrm{~m}$ observation blinds. The blinds were located at a distance from where 10 or more active puffin burrows were visible within 5-20 m of the blind. Observers conducted 3-h observation stints at different times of the day that spanned the entire chick-rearing season from mid-June through early August, for a total of about $120 \mathrm{~h} /$ island/year. For each observed prey delivery, the species and estimated size of each prey item were recorded. In our analysis, we included only identified prey items; an average of 13\% (range $0-30 \%$ ) of prey items delivered each year were unidentified due to insufficient views of the feeding.

The efficacy of training observers to accurately identify the foods in puffin bill loads was independently demonstrated by Bowser et al. (2013). Additionally, to verify the composition of prey loads, we collected specimens dropped near nests and used photographs to confirm identification of prey. Photographs were taken with a Canon 7D SLR with a $300 \mathrm{~mm}$ telephoto lens equipped with a 1.4 extender.

Voucher specimens collected from chicks and near nests were identified by staff at the Sandy Hook Marine Lab, Highlands, NJ, the Maine Department of Marine Resources in Boothbay Harbor, ME, or the National Marine Fisheries Service, Northeast Fisheries Center. On laboratory examination of specimens obtained, pelagic-juvenile Urophysis proved to be white hake (Urophycis tenuis). Redfish were not identified to species in the bill loads delivered by parent puffins to their chicks; so we refer to this group as Sebastes spp. However, all collected specimens were identified as Acadian redfish (Sebastes fasciatus).

To determine the "prey signature" for each island, we added the number of specimens of each prey species delivered by all puffins and divided this by the total number of identified prey items (of all prey species) to arrive at a percent by number for each of the 10 years. We then computed the median percentage for each species observed. We used the median rather than the mean to reduce sensitivity to unusually high or low percentage values. We defined the "signature" of a puffin colony by ranking the three prey species with the highest median percentages. To see if the signature changed over the 10 year period, we compared the three most frequently delivered prey during two 5-year observation periods, 2005-2009 (early) and 2010-2014 (late).

\section{Hatching and productivity changes}

We measured hatching success as the percent of eggs that hatched and productivity as the percent of nests that produced a fledgling. We examined whether hatching success or productivity had changed significantly over the years 2004-2014 for Matinicus Rock, and 2006-2014 for Seal Island. Nesting burrows are largely inaccessible at Eastern Egg Rock. Hence, this island was excluded from hatching and productivity studies. We began measuring productivity parameters at Matinicus Rock in 2004, conducting a direct observation of approximately 50-75 puffin nests each year, and followed the same protocol at Seal Island beginning in 2006 when the colony had grown large enough to sample a similar number of nests.

Burrows were checked for eggs, starting in mid- to late-May. Once an egg was found, burrows were not checked again until hatching was expected, and then they were checked every 4 days until hatch was detected. After hatching, burrows were checked periodically (every 1-2 weeks) until it was determined that the chick fledged or the nest failed. Due to annual variation in burrow occupancy and breeding activity, the number of active monitored burrows each year ranged from 37 to 78 per island. The final fate of a small number of nests that hatched late in the season each year could not be determined, and these were excluded from productivity calculations. 
We analyzed data of all years at both islands and then compared an early period (2004-2009 for Matinicus Rock and 2006-2009 for Seal Island) with a later period, 2010-2014 at both islands. We chose 2010 as a break point using a statistical measurement called the total sum of squared errors (SSEs). We computed this based on two separate linear regression models, one for 2004/2006 through the "splitting year" (SY) and then the next year through 2014. We selected the splitting year that produced the lowest total SSE value as the best model fit. In this manner, the dataset was split into two sets, the first from 2004 through SY, and then from SY + 1 through 2014 for all years 2005 through 2014. Finally, with two islands, each of which featured an analysis of hatching and productivity success, there were four different splitting years to consider, and it was desirable to choose the same splitting year per analysis. The year 2010 was the best for productivity for both islands. For hatching success, 2010 was the second best for Matinicus Rock behind 2009, whereas 2010 was third best for Seal Island behind 2008 and 2009. Clearly the optimal overall splitting year is between 2008 and 2010; therefore, 2010 was selected because it produced the lowest total SSE twice, whereas the other two years only produced the lowest total SSE once each.

To test for changes in hatching success and productivity, we fit least squares linear regression models to both the early and later periods. We also used least squares linear regressions for the full study period. However, in the case of Seal Island productivity, we used median regression (quantile regression) due to outliers in the data. The explanatory variable (i.e., independent) was always the year, and the response variable was either the hatching success or productivity. We express the proportion between 0 and 1 because of the puffin's one egg clutch.

\section{Chick condition and return rate}

We compared condition of chicks at Matinicus Rock and return rate (percent of cohort resighted) as a function of year for the period 1993-2009. Chick condition is reflected in the weight/wing chord ratio of puffin chicks measured during the linear growth stage (age 10-30 days, although most chicks were measured between days 21 and 30). We selected the linear growth stage chicks because puffin chicks typically lose weight during the final week before fledging, a fact that would affect the accurate comparison of weight/wing chord ratio between chicks. A total of 888 puffin chicks were included in this sample.

Chicks were removed from their burrows for banding with a USGS issued band in combination with a field readable band (USGS banding permit No. 20308). We measured unflattened wing chord with a $30 \mathrm{~cm}$ stopped wing ruler. Weight (mass) was measured by placing each chick in a cloth bag suspended from a 300 or $500 \mathrm{~g}$ capacity Pesola scale. The data that we used for chick condition is a weight/wing ratio, measured only during the linear growth phase. These data were obtained only at the time of banding, and thus, there was just one data point for each bird, rather than a series of data points over time. Hence, providing variance around this data point for each bird was not possible.

Most puffin chicks typically spend their first 2 or 3 years at sea before returning to land (Kress and Nettleship 1988), but some are not sighted on land until they are 5 years old. For Matinicus Rock puffins, we determined that at least $95 \%$ of surviving puffin chicks will have been resighted on land by 5 years after fledging. Because resighting effort was very thorough at all five puffin breeding colonies in the Gulf of Maine (the three study islands as well as the nearby puffin colonies at Machias Seal Island, New Brunswick, and Petit Manan National Wildlife Refuge, Maine), we believe that we resighted most of the returning puffins. We use the return rate of banded birds as a metric that approximates survival, an approach that is common in avian studies (Hamel et al. 2004; Oro et al. 2011). To allow for maturation at sea by some individuals, we did not include chicks weighed and 
measured during 2010-2014 period in this analysis of returning birds. The number of chicks in each banded cohort ranged from 37 to 105 .

To determine if there was a difference in postfledging survival in relation to the chick condition, we used a $T$-test comparing the weight/wing cord ratio of 612 chicks that were later resighted at any breeding colony in the Gulf of Maine and 276 chicks that were not resighted.

\section{Determining if there was a change point in chick condition}

To determine if there may have been a change in the trajectory of condition and/or survival over this 19-year period, we examined the data for a change point using the regression statistic $R$-squared $\left(R^{2}\right)$. This measurement indicates how well the model fits the data, and values closer to 1 indicate better fit. The $R$-squared value was computed based on two separate linear regression models, one for 1993 through the "splitting year" (SY) and then the next year through 2009. We selected the splitting year that produced the highest $R$-squared value as the best model fit. In this manner, the dataset was split into two sets, the first from 1993 through SY, and then from SY + 1 through 2009, for all years 1994 through 2009. Because there are many data points and considerable dispersion, the $R$-squared value is naturally low (usually between 0.10 and 0.15 ).

\section{Results}

\section{Diet: Prey signatures}

Although the three puffin colonies investigated in this study are relatively close together, the constellation of prey delivered (i.e., prey signature) varied between islands, though several key species dominated the catch at all islands (Fig. 2).

We have analyzed changes (Fig. 3) and included statistics for those that made significant changes. Eastern Egg Rock puffin chick diet has remained relatively constant over the 10-year period (2005-2014), with white hake (Urophysis tenuis) comprising about $75 \%$ of the identified food items delivered to chicks throughout the study. Likewise, Atlantic herring (Clupea harengus) was a consistent second most important food throughout the 10-year study period. American butterfish (Peprilus triacanthus) doubled in frequency within chick diet from the first half of the study to the second $\left(Z\right.$-statistic $=-4.6610, p$-value $\left.=3.15 \times 10^{-6}\right)$ but still comprised only about $5 \%$ of food items in the later period. Redfish (Sebastes spp.), previously unknown at Eastern Egg Rock since 2005, comprised nearly 10\% of food items in 2013 and 2014.

Matinicus Rock puffins fed their chicks predominantly on a diet of white hake throughout the study, especially in the first half of the study; herring and sand lance (Ammodytes dubius) are represented in the puffin chick diet by occasional "boom" years (e.g., Atlantic herring comprised $72 \%$ of food items in 2009 and sand lance comprised $42 \%$ of food in 2008). In the recent period, herring has declined from the third to fourth most frequently delivered food $(Z$-statistic $=2.6976$, $p$-value $=0.0070)$; haddock (Melanogrammus aeglefinus), not even observed in the first half of the study, has increased in abundance to the second most frequently delivered food; butterfish (though still far below other foods) has increased to the third most frequently delivered food $(Z$-statistic $=-2.3298, p$-value $=$ 0.0198). Also, redfish (Sebastes spp.) was not detected in the first half of the study, but it began showing up in the puffin diet in 2011 when it comprised about $24 \%$ of food items delivered to puffin chicks. Since 2011, it has remained a consistent addition to the diet.

Seal Island puffins delivered more Atlantic herring to their chicks in the first half of the study than other foods, but herring was replaced as the most frequently delivered food by white hake in the second half of the study $\left(Z\right.$-statistic $=-10.1377, p$-value $\left.=3.84 \times 10^{-24}\right)$. As at Matinicus Rock, sand 


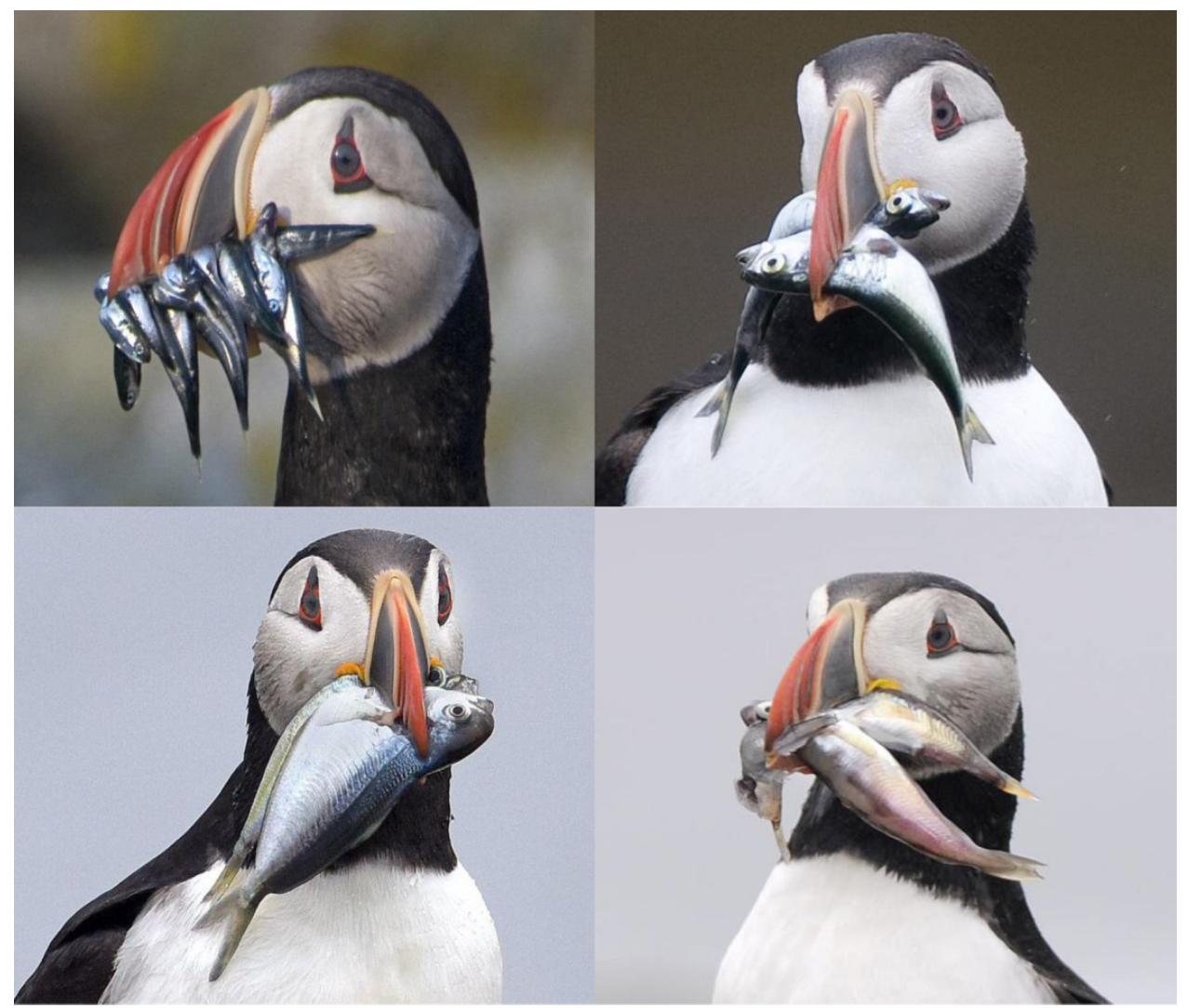

Fig. 2. White hake (upper left) dominates the food of puffin chicks at all Maine islands, but is among species shifting their range northward in response to warming seas. Atlantic herring (upper right), a commercially important source of lobster bait, is the second most important fish, but it has declined in the puffin chick diet in recent years at two colonies. Butterfish (lower left) is a warmer water fish that is increasing at all islands, but it is sometimes too broad in shape for chicks to swallow. Haddock (the longer fish in lower right photo) and Acadian redfish (smaller fish in lower right photo) are from recovering fish stocks. Both were unknown in the puffin chick diet in the first half of the study, but are now regular additions to the chick diet at all Maine puffin colonies. Photo credit: Derrick Z. Jackson. Used with permission.

lance was important in certain years, but as it is highly variable, comprising $44 \%$ of food items in 2007 and $20 \%$ in 2014, it falls to less than $1 \%$ in 4 of the 10 years. Butterfish, not in the top four foods for 2005-2009, has increased to the third most common prey in the 2010-2014 period ( $Z$-statistic $=$ $-13.8411, p$-value $\left.=1.50 \times 10^{-43}\right)$. Also, as at Matinicus Rock, haddock first appeared at Seal Island in 2010 when it comprised up to $42 \%$ of food items and has remained a regular, though smaller part of the diet since 2010 (Fig. 3).

\section{Hatching and productivity changes}

\section{Matinicus Rock}

Hatch success and productivity remained constant from 2004 through 2009 and began to decline in 2010; the deepest declines occurred in 2012 and 2013. During the years 2010-2013, hatching success 


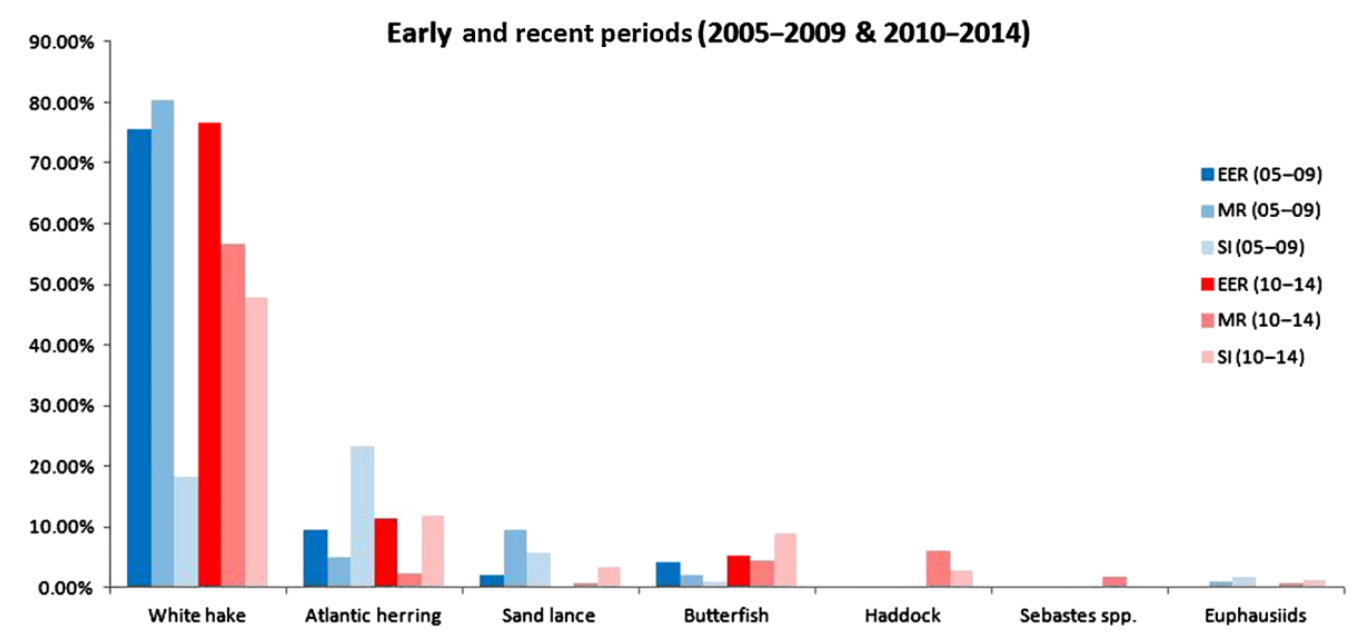

Fig. 3. Median percentages of prey delivered to puffin chicks at Eastern Egg Rock (EER), Matinicus Rock (MR), and Seal Island (SI). White hake dominates the prey at all three islands, especially at EER and MR, increasing at SI in the recent half of the study. In the recent period, Atlantic herring has declined at Seal Island and Matinicus Rock, whereas butterfish, haddock, and Sebastes spp. have become more prevalent, though still less than $10 \%$ of chick diet.

declined significantly by 10.5 percentage points ( $T$-statistic $=-5.9155, p$-value $=0.0274$ ) per year and productivity declined significantly by 19.2 percentage points per year $(T$-statistic $=-5.0288$, $p$-value $=0.0373$ ) over the same 4 years. In 2014, hatching success and productivity returned to the level of the 2004-2009 period (Fig. 4).

\section{Seal Island}

In the early period at Seal Island (2006-2009), hatching success decreased significantly by 4.00 percentage points per year $(T$-statistic $=-6.3241, p$-value $=0.0241)$ and by 11.40 percentage points per year $(T$-statistic $=-6.3545, p$-value $=0.0239)$ during the more recent period $(2010-2013)$. Similarly, on average, productivity significantly decreased by 5.50 percentage points per year $(T$-statistic $=-6.3510, p$-value $=0.0239)$ over $2006-2009$ and by 24.50 percentage points per year
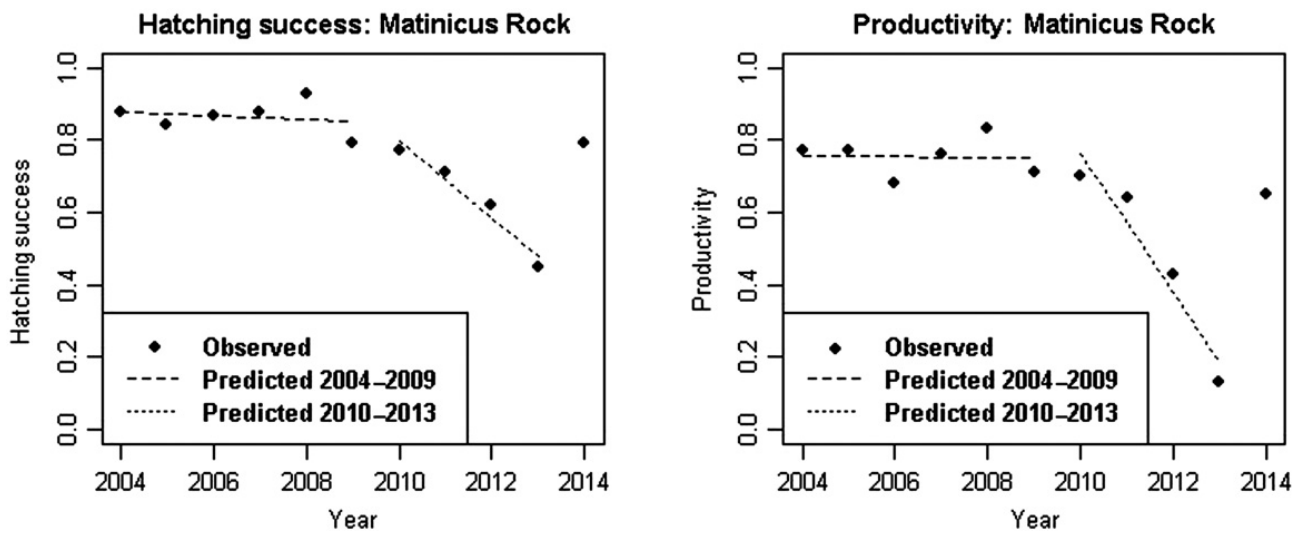

Fig. 4. At Matinicus Rock, puffin hatching success and productivity did not change during the period 2004-2009, but declined during the period 2010-2013, rebounding in 2014. 

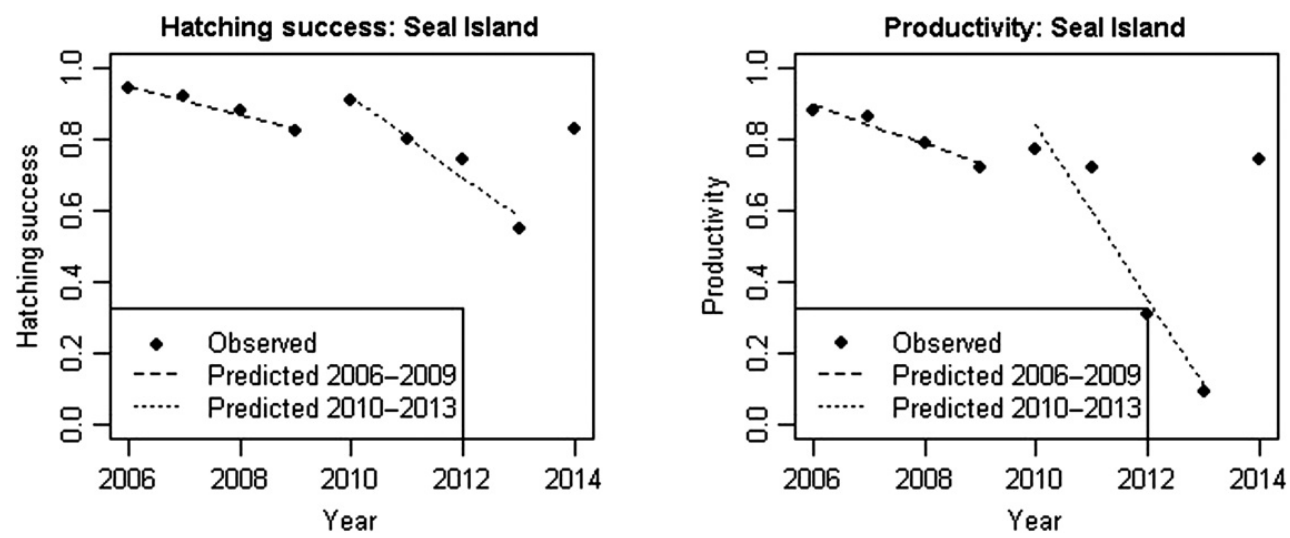

Fig. 5. At Seal Island, hatching declined by $4 \%$ during the years $2006-2009$ and by $11.4 \%$ in the more recent period of $2010-2013$. Likewise, productivity declined by $5.5 \%$ in the early period and $24.5 \%$ in the later period.

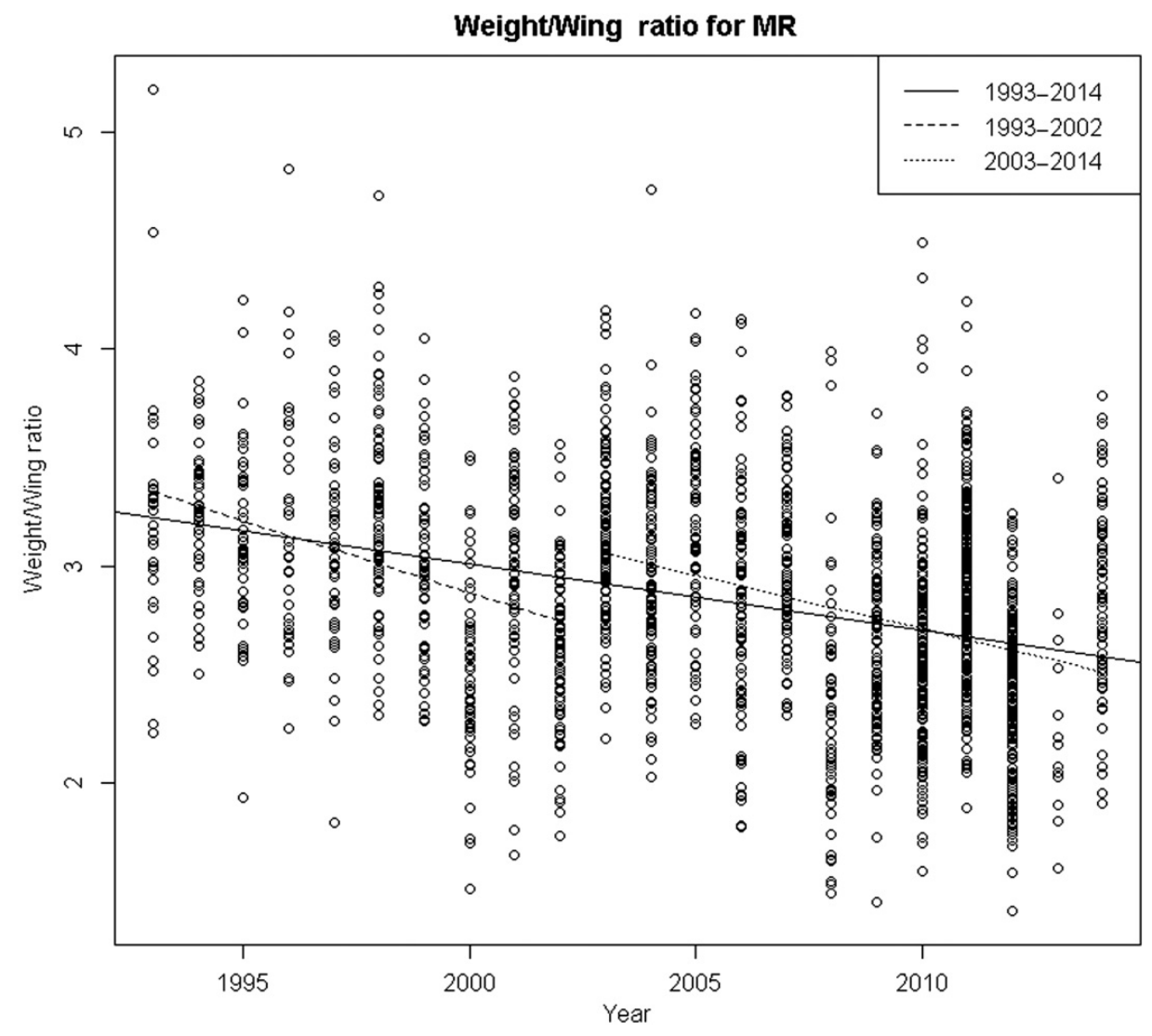

Fig. 6. The weight/wing ratio of all puffin chicks at Matinicus Rock over the full study period, 1993-2009 (solid line). The dashed line illustrates the lesser decline from 1993 to 2002; the dotted line illustrates the greater decline from 2003 to 2009. 
$(T$-statistic $=-5.1819, p$-value $=0.0353)$ over 2010-2013. Similarly to Matinicus Rock, both hatching success and productivity returned to the range of the early period in 2014 (Fig. 5).

\section{Change in chick condition}

From 1993 to 2009, the weight/wing chord ratio of puffin chicks significantly declined by an average of 0.0305 units per year $\left(T\right.$-statistic $=-15.4411, p$-value $\left.=1.38 \times 10^{-50}\right)$. The weight $/$ wing chord ratio significantly declined by an average of 0.0663 units/year from 1993 to 2002 ( $T$-statistic $=$ $-9.1908, p$-value $\left.=7.58 \times 10^{-19}\right)$ and by 0.0936 units/year from 2003 to $2009(T$-statistic $=$ $-10.2291, p$-value $\left.=1.24 \times 10^{-22}\right)($ Fig. 6).

\section{Postfledging survival}

The percent return of Matinicus Rock puffin cohorts (with individuals resighted at age 2 years or older) varies between years from about $40 \%$ to $90 \%$ with the lowest percent returns in the most recent years. The percentage of each cohort resighted has significantly decreased by 2.525 percentage points per year for 1993-2009 cohorts $(T$-statistic $=-5.3013, p$-value $=0.0001)($ Fig. 7$)$.

The mean weight/wing chord ratio is significantly different between chicks that survived and chicks that were not resighted $(p<0.001)$. On average, survivors had a $6.4 \%$ higher weight/wing chord ratio than nonsurvivors $\left(T\right.$-statistic $=5.6182, p$-value $\left.=2.82 \times 10^{-8}\right)($ Fig. 8$)$.

\section{Discussion}

Seabirds are well-known for their responsiveness to changes in marine conditions that affect their forage fish and other prey (Diamond and Devlin 2003; Frederiksen et al. 2004; Grosbois and Thompson 2005). The Gulf of Maine is especially susceptible to such changes and by some estimates is among the fastest warming waters on Earth (Mills et al. 2013; Pershing et al. 2015). The trend toward

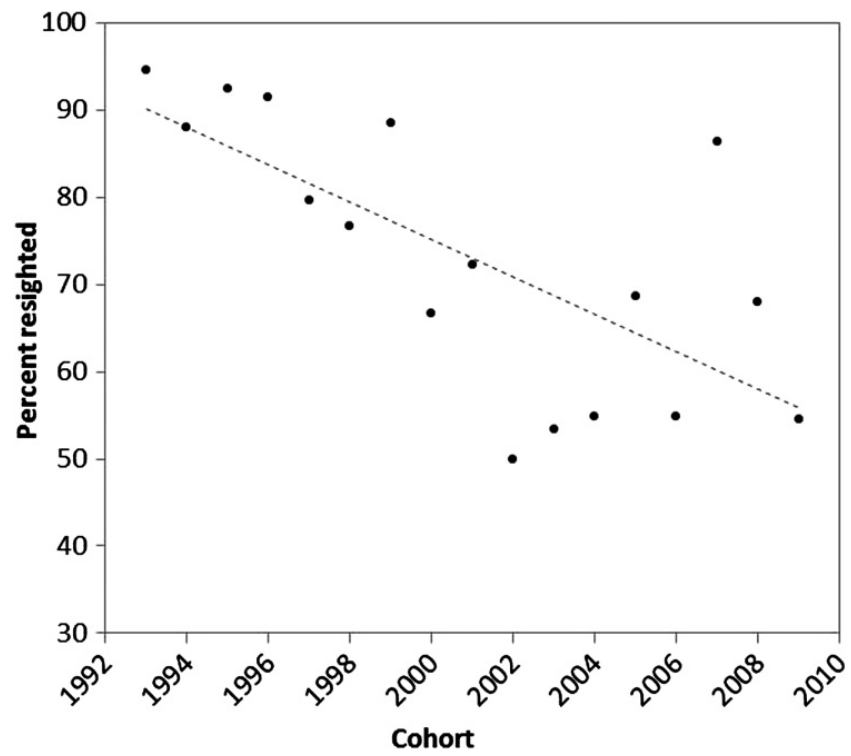

Fig. 7. Percent of each Matinicus Rock puffin cohort resighted demonstrates the trend of reduced juvenile survival of Matinicus Rock puffins since 1993. The percentage resighted is, on average, decreasing by 2.525 percentage points per year. 

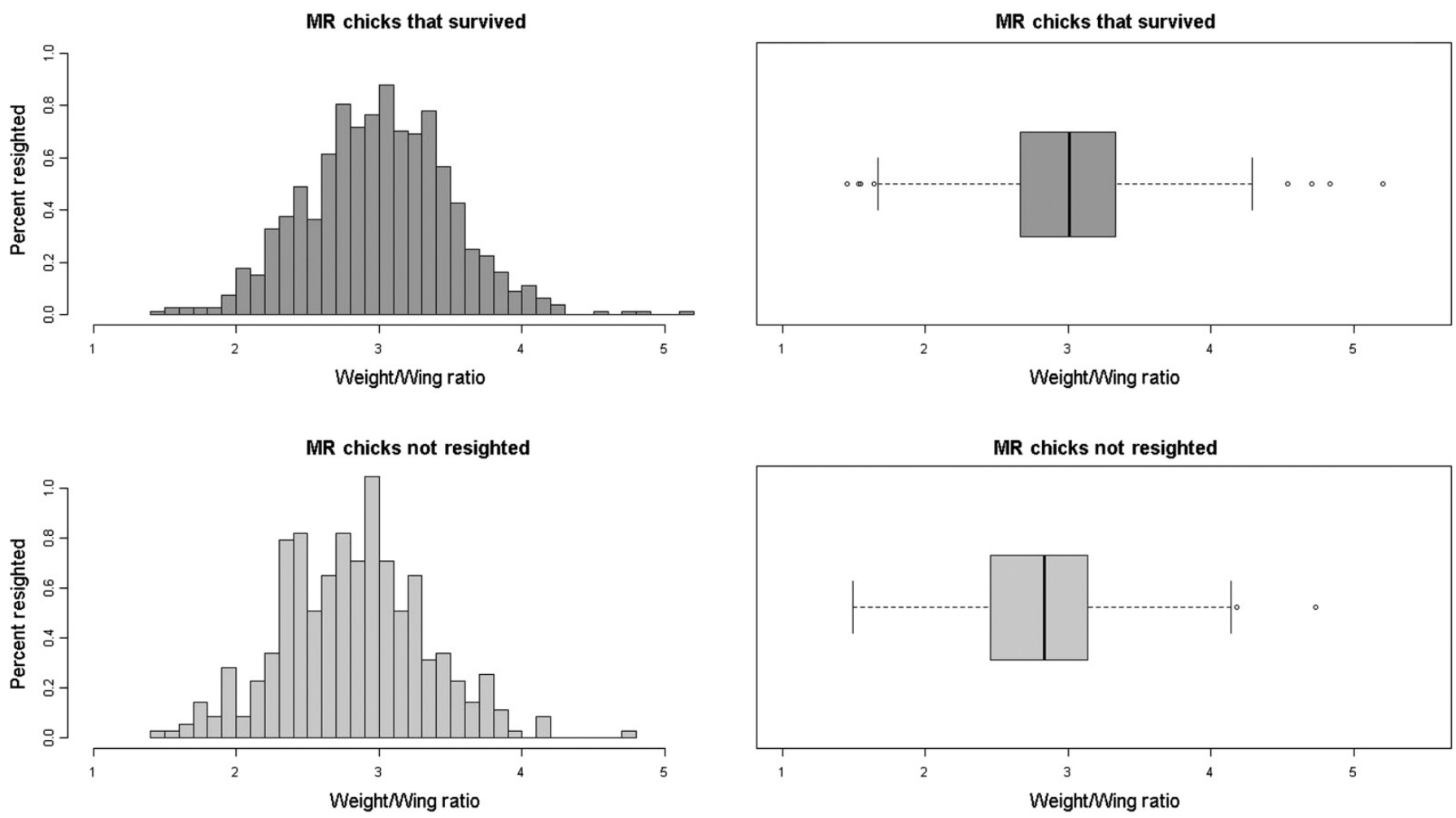

Fig. 8. Puffin chicks with greater weight/wing ratios were $6.4 \%$ more likely to have survived to at least 2 years of age.

warming water temperature has been linked to shifts in the distribution of many northern fish stocks, some of which are key forage fish for puffins (Rose 2005). Nye et al. (2009) found that 24 of 36 stocks displayed significant changes consistent with warming, as indicated by poleward shifts in the center of biomass and increased mean depth of occurrence and/or an increase in mean ocean temperature. One among these is white hake, consistently the most important forage fish for Maine puffins.

During the most recent 5 years of this study, we documented several notable changes in the foods delivered to puffin chicks. These changes (Table 1) include a decline in Atlantic herring and increases in butterfish, haddock, and redfish. The decline in Atlantic herring observed in the puffin chick diet in this study is consistent with the herring's sensitivity to warming waters (Rose 2005) and intense fishing pressure in the vicinity of the puffin nesting colonies (NEFMC 2010). The herring fishery takes most of its annual allowable limit, which is currently set based upon single-species Maximum Sustainable Yield (MSY) (see Atlantic herring specifications for 2016-2018), and without consideration of the specific needs of predators such as marine mammals, tuna, and seabirds (Read and Brownstein 2003).

An amendment to the management plan is underway, which is expected to bring catch setting into alignment with current views on ecosystem-based fisheries management (NOAA Fisheries Service 2015). For example, in 2014, the herring fishery was closed by NMFS when it exceeded $92 \%$ of allowable catch in Management Area 1A, a fishing ground that stretches from Cape Cod to the US Canadian border. Here, about 100000 MT of Atlantic herring are caught annually by highly efficient midwater trawls with about $80 \%$ of the catch used for lobster bait (Lehuta et al. 2014). Until the late 
Table 1. Prey fed to puffin chicks at midcoast Maine colonies ranked as median percentage by number of items delivered to chicks. (\#) represents rank from 1 to 3 .

\begin{tabular}{|c|c|c|c|c|c|c|c|c|c|}
\hline \multirow[b]{2}{*}{ Species } & \multicolumn{3}{|c|}{ Eastern Egg Rock } & \multicolumn{3}{|c|}{ Matinicus Rock } & \multicolumn{3}{|c|}{ Seal Island } \\
\hline & 2005-2014 & 2005-2009 & 2010-2014 & 2005-2014 & 2005-2009 & 2010-2014 & 2005-2014 & 2005-2009 & 2010-2014 \\
\hline White hake & (1) $76.64 \%$ & (1) $75.47 \%$ & (1) $76.64 \%$ & (1) $57.36 \%$ & (1) $80.38 \%$ & (1) $56.54 \%$ & (1) $38.58 \%$ & (2) $18.27 \%$ & (1) $47.88 \%$ \\
\hline Atlantic herring & (2) $11.27 \%$ & (2) $9.55 \%$ & (2) $11.27 \%$ & (3) $4.01 \%$ & (3) $4.96 \%$ & $2.40 \%$ & (2) $17.66 \%$ & (1) $23.44 \%$ & (2) $11.87 \%$ \\
\hline Sand lance & $0.29 \%$ & $2.04 \%$ & $0.29 \%$ & (2) $8.53 \%$ & (2) $9.47 \%$ & $0.77 \%$ & (3) $4.63 \%$ & (3) $5.84 \%$ & $3.41 \%$ \\
\hline Butterfish & (3) $5.37 \%$ & (3) $4.20 \%$ & (3) $5.37 \%$ & $2.71 \%$ & $1.99 \%$ & (3) $4.44 \%$ & $1.83 \%$ & $0.98 \%$ & (3) $9.05 \%$ \\
\hline Haddock & $0.00 \%$ & $0.00 \%$ & $0.00 \%$ & $1.03 \%$ & $0.00 \%$ & (2) $6.08 \%$ & $0.33 \%$ & $0.00 \%$ & $2.80 \%$ \\
\hline Sebastes spp. & $0.00 \%$ & $0.00 \%$ & $0.00 \%$ & $0.00 \%$ & $0.00 \%$ & $1.74 \%$ & $0.00 \%$ & $0.00 \%$ & $0.00 \%$ \\
\hline Euphausiids & $0.00 \%$ & $0.30 \%$ & $0.00 \%$ & $0.74 \%$ & $0.97 \%$ & $0.71 \%$ & $1.58 \%$ & $1.88 \%$ & $1.28 \%$ \\
\hline Bluefish & $0.29 \%$ & $0.84 \%$ & $0.29 \%$ & $0.00 \%$ & $0.00 \%$ & $0.31 \%$ & $0.00 \%$ & $0.00 \%$ & $0.00 \%$ \\
\hline Atlantic mackerel & $0.23 \%$ & $0.19 \%$ & $0.24 \%$ & $0.00 \%$ & $0.00 \%$ & $0.00 \%$ & $0.00 \%$ & $0.00 \%$ & $0.00 \%$ \\
\hline Atlantic saury & $0.15 \%$ & $0.07 \%$ & $0.26 \%$ & $0.15 \%$ & $0.59 \%$ & $0.00 \%$ & $0.00 \%$ & $0.00 \%$ & $0.62 \%$ \\
\hline Atlantic pollock & $0.32 \%$ & $0.19 \%$ & $0.36 \%$ & $0.34 \%$ & $0.34 \%$ & $0.33 \%$ & $0.17 \%$ & $0.26 \%$ & $0.10 \%$ \\
\hline
\end{tabular}

1950s, annual herring catch in New England averaged about 60000 MT. Landings averaged about $60,000 \mathrm{mt}$ (about 132 million pounds) throughout the 1890s and early 1900s. Due to foreign fishing impacts, the catch increased to $477,000 \mathrm{mt}$ in 1968 . This excessive harvest led to the collapse of the offshore herring stock (ASMFC 2016) and new regulations in 1976 under the Magnuson-Stevens Act (Dell'Apa et al. 2012).

If haddock and redfish have sufficient caloric values and abundance near nesting colonies to provide ample nutrition for chicks, then the most recent 5-year period of this study is a promising development for puffins-one which parallels the successful management of both haddock and redfish under the Magnuson-Stevens Act. Strict management measures such as time and area closures, fishing gear restrictions, and minimum fish size limits have contributed to the recovered populations (NFSC 2014). As a result of these actions, haddock and Acadian redfish in the Gulf of Maine have rebuilt their populations following decades of overfishing (NOAA fishwatch 2014a, 2014b, 2014c).

The quality of haddock, Acadian redfish, and other emerging species in the puffin's diet needs to be carefully assessed; otherwise, simply switching to a different diet will not necessarily serve as a viable replacement for Atlantic herring and white hake (Diamond and Devlin 2003; Wanless et al. 2005). Although butterfish only comprised a small portion of the puffin diet throughout this study, it could prove problematic for puffins if its range shifts further north from its current distribution centered in the Mid-Atlantic Bight (Frank et al. 1990). In 2012, the year of exceptionally warm waters (Mills et al. 2013), puffins fed their chicks large butterfish and insufficient amounts of the usual prey. In this year, only about a third of puffin pairs at Seal Island and Matinicus Rock fledged chicks.

The declining body weights of puffin chicks in the Gulf of Maine (Fig. 6) are consistent with the trend for increasing sea surface temperature (SST) and a decline in the primary productivity in the Gulf of Maine (Balch et al. 2012; Pershing et al. 2005). Temperatures in the Gulf of Maine have increased by an average of $0.026{ }^{\circ} \mathrm{C} /$ year since 1982 , but the pace of warming accelerated to $0.26^{\circ} \mathrm{C} /$ year after 2005 (Mills et al. 2013). 
This warming is associated with accelerated ice melt in the Arctic and concomitant freshening of the region from the Labrador Sea to the Gulf of Maine. Since the 1970s, there has been an associated shift in nutrients entering the deep regions of the Gulf of Maine as waters have become fresher, cooler, and depleted in nitrates (Townsend et al. 2010). At the same time, increased precipitation and associated runoff from rivers entering the Gulf of Maine are bringing more organic colloids (ultramicroscopic particles are so small that they do not settle and cannot be separated by ordinary filtration) that reduce carbon fixation by phytoplankton (Balch et al. 2012). These factors contribute to diminished concentrations of oil-rich zooplankton such as Calanus finmarchicus (Pershing et al. 2005; Friedland et al. 2013), one of the principal foods of puffin forage fish. The onset of the increase in SST described by Mills et al. (2013) is consistent with the decline in primary productivity described by Balch et al. (2012) along a study transect from Portland, Maine to Yarmouth, Nova Scotia, after 2005, a region that is within the Gulf of Maine where puffins spend much of the year.

Similar to the decline in chlorophyll biomass detected after 2005 by Balch et al. (2012) in their transect study, we detected a steeper decline in the puffin chick body condition (as indicated by the body weight/wing chord ratio) beginning after 2003 (Fig. 6). This is similar to the beginning of a decline in puffin productivity at Machias Seal Island associated with an end to herring as the principal food for puffins in 2000 (Diamond and Devlin 2003).

Puffin fledglings are especially vulnerable to reduced body mass and associated fat reserves because parent puffins do not feed their chicks postfledging. It is not surprising, therefore, that we found a trend demonstrating that chicks with lower weight/wing chord ratios are less likely to survive (Fig. 7) and that surviving puffins had on average a $6.4 \%$ greater weight/wing chord as chicks (Fig. 8). As puffin fledglings receive no parental care after they head to sea, those with greater body mass at fledging have an advantage over those with lower mass since the additional mass provides energy and insulation for the fledgling as it adapts to life at sea.

The great decline in both puffin hatching success and productivity during the 2010-2013 period results mostly from the nesting failures in 2012 and 2013. These occurred during the largest and most intense warming event in the Northwest Atlantic in the last 30 years. The "ocean heat wave" of 2012 affected the region from Cape Hatteras to Iceland and northward into the Labrador Sea where sea surface temperature was $1-3^{\circ} \mathrm{C}$ warmer than the 1982-2011 average (Mills et al. 2013). Extreme events such as this are a predicted effect of global climate change (Hansen et al. 2012) and could serve as a predictor of events to come.

Because the low hatching rate results from egg abandonment, we speculate that parent puffins abandon their eggs when they cannot find ample food for themselves (Catry et al. 2013). Likewise, if parents hatched the egg, but found insufficient food near the nesting island, chick development suffered, often leading to starvation. In 2013 , food was so scarce that only about $10 \%$ of puffin pairs at Matinicus Rock and Seal Island succeeded in fledging chicks, compared to about $75 \%$ of pairs fledging a chick in the years prior to 2010 .

It is possible that 2014 marked the beginning of another successful period, as about $75 \%$ of puffin pairs fledged chicks. This improved productivity resulted from sufficient supplies of white hake, herring, and sand lance, supplemented by haddock and redfish. The puffin's innate behavioral responses such as forfeiting breeding in years of less food and its adaptive use of recovering and new fish stocks point to the puffins' ability to adapt to changing environments. This study demonstrates that puffins are sensitive indicators to climate effects. The magnitude, frequency, and duration of extreme climate events such as the heat wave of 2012 as well as the extent of changes in productivity of the Gulf of Maine will ultimately determine the puffin's ability to adapt to impending changes in the Gulf of Maine. 


\section{Acknowledgements}

The authors thank the research assistants of the Audubon Seabird Restoration Program for their care in collecting the forage fish data summarized here. They are grateful to Michael Fahey for help in identifying fish and Robert Houston, USFWS for the map. They also thank Anthony W. Diamond, John Crawford, Katie Matthews, and Elissa Wolfson for their comments on early drafts of this paper. The authors acknowledge support for this study from the Pew Charitable Trusts and supporters of the Audubon Seabird Restoration Program.

\section{Author contributions}

Conceived and designed the study: SW, PS. Performed the experiments/collected the data: SW, PS. Analyzed and interpreted the data: SW, PS, CO. Contributed resources: SW, PS, CO. Drafted or revised the manuscript: SW, PS, CO.

\section{Data accessibility statement}

All relevant data are within the paper.

\section{References}

Atlantic States Marine Fisheries Commission (ASMFC). 2016. Atlantic Herring [online]: Available from http://www.asmfc.org/species/atlantic-herring [accessed 15 April 2016].

Balch WM, Drapeau DT, Bowler BC, and Huntington TG. 2012. Step-changes in the physical, chemical and biological characteristics of the Gulf of Maine, as documented by the GNATS time series. Marine Ecology: Progress Series, 450: 11-35. doi:10.3354/meps09555.

Barrett RT. 2002. Atlantic puffin Fratercula arctica and common guillemot Uria aalge chick diet and growth as indicators of fish stocks in the Barents Sea. Marine Ecology: Progress Series, 230: 275-287. doi:10.3354/meps230275.

Barrett RT, and Rikardsen F. 1992. Chick growth, fledging periods and adult weight loss of Atlantic puffins, Fratercula arctica, during years of prolonged food stress. Colonial Waterbirds, 15: 24-32. doi:10.2307/1521351.

Bell RJ, Richardson DE, Hare JA, Lynch PD, and Fratantoni PS. 2014. Disentangling the effects of climate, abundance, and size on the distribution of marine fish: an example based on four stocks from the Northeast US shelf. ICES Journal of Marine Science, 72(5): 1311-1322. doi:10.1093/ icesjms/fsu217.

Bowser AK, Diamond AW, and Addison JA. 2013. From puffins to plankton: A DNA-based analysis of a seabird food chain in the northern Gulf of Maine. PLoS ONE, 8(12): e83152. PMID:24358258. doi:10.1371/journal.pone.0083152.

Burger AE, and Simpson M. 1986. Diving depths of Atlantic puffins and common murres. Auk, 103: 828-830.

Catry T, Ramos JA, Catry I, Monticelli DJP, and Granadeiro D. 2013. Inter-annual variability in the breeding performance of six tropical seabird species: Influence of life-history traits and relationship with oceanographic parameters. Marine Biology, 160(5): 1189-1201. doi:10.1007/s00227-013-2171-2.

Cury PM, Boyd IL, Bonhommeau S, Anker-Nilssen T, Crawford RJM, Furness RW, Mills JA, Murphy EJ, Österblom H, Paleczny M, Piatt JF, Roux J, Shannon L, and Sydeman WJ. 2011. Global seabird 
response to forge fish depletion—one-third for the birds. Science, 334: 1703-1706. PMID:22194577. doi:10.1126/science.1212928.

Dell'Apa A, Schiavinato L, and Rulifson RA. 2012. The Magnuson-Stevens act (1976) and its reauthorizations: Failure or success for the implementation of fishery sustainability and management in the US? Marine Policy, 36(3): 673-680. doi:10.1016/j.marpol.2011.11.002.

Diamond A, and Devlin C. 2003. Seabirds as indicators of changes in marine ecosystems: Ecological monitoring on Machias Seal Island. Environmental Monitoring and Assessment, 88: 153-181. PMID:14570414. doi:10.1023/A:1025560805788.

Drury WH. 1973. Population changes in New England seabirds. Bird-Banding, 44: 267-313. doi:10 $.2307 / 4511982$.

Eilertsen K, Barrett RT, and Pedersen T. 2008. Diet, growth and early survival of Atlantic puffin (Fratercula arctica) chicks in North Norway. Waterbirds, 31: 107-114. doi:10.1675/1524-4695(2008) 31[107:DGAESO]2.0.CO;2.

Fogarty M. 2014. The art of ecosystem-based fishery management. Canadian Journal of Fisheries and Aquatic Sciences, 71: 479-490. doi:10.1139/cjfas-2013-0203.

Frank KT, Perry RI, and Drinkwater KF. 1990. Predicted response of northwest Atlantic invertebrate and fish stocks to $\mathrm{CO}_{2}$-induced climate change. Transactions of the American Fisheries Society, 119 (2): 353-365. doi:10.1577/1548-8659(1990)119<0353:PRONAI>2.3.CO;2.

Frederiksen M, Wanless S, Harris M, Rothery P, and Wilson L. 2004. The role of industrial fisheries and oceanographic change in the decline of North Sea black-legged kittiwakes. Applied Ecology, 41: 1129-1139. doi:10.1111/j.0021-8901.2004.00966.x.

Friedland KD, Kane J, Hare JA, Lough RG, Fratantoni PS, Fogarty MJ, and Nye JA. 2013. Thermal habitat constraints on zooplankton species associated with Atlantic cod (Gadus morhua) on the US Northeast Continental Shelf. Progress in Oceanography, 116: 1-13. doi:10.1016/j.pocean .2013.05.011.

Grosbois V, and Thompson P. 2005. North Atlantic climate variation influences survival in adult fulmars. Oikos, 109(2): 273-290. doi:10.1111/j.0030-1299.2005.13774.x.

Hamel N, Parrish JK, and Conquest LL. 2004. Effects of tagging on behavior, provisioning, and reproduction in the Common Murre (Uria aalge), a diving seabird. Auk, 121(4): 1161-1171. doi:10.1642/ 0004-8038(2004)121[1161:EOTOBP]2.0.CO;2.

Hansen J, Sato M, and Ruedy R. 2012. Perception of climate change. Proceedings of the National Academy of Sciences of the United States of America, 109: E2415-E2423. PMID:22869707. doi:10.1073/pnas.1205276109.

Harris MP, and Wanless S. 2012. The puffin. Yale University Press, New Haven and London. $256 \mathrm{p}$.

Jones HP, and Kress SW. 2012. A review of the world's active seabird restoration projects. The Journal of Wildlife Management, 76(1): 2-9. doi:10.1002/jwmg.240.

Kress SW, and Nettleship DN. 1988. Re-establishment of Atlantic puffins (Fratercula arctica) at a former breeding site in the Gulf of Maine. Journal of Field Ornithology, 59(2): 161-170. 
Lehuta S, Holland DS, and Pershing AJ. 2014. Investigating interconnected fisheries: A coupled model of the lobster and herring fisheries in New England. Canadian Journal of Fisheries and Aquatic Sciences, 71(2): 272-289. doi:doi:10.1139/cjfas-2013-0185.

Mills KE, Pershing AJ, Brown CJ, Chen Y, Chiang FS, Holland DS, Lehuta SJ, Nye A, Sun JC, Thomas AC, and Wahle RA. 2013. Fisheries management in a changing climate: Lessons from the 2012 ocean heat wave in the Northwest Atlantic. Oceanography, 26(2): 191-195. doi:10.5670/oceanog.2013.27.

Northeast Fisheries Science Center (NFSC). 2014. Gulf of Maine haddock benchmark stock assessment for 2014. 59th Northeast Regional Stock Assessment Workshop Assessment Report [online]: Available from http://nefsc.noaa.gov/publications/crd/crd1409/parta.pdf [accessed 15 September 2015].

National Oceanic and Atmospheric Administration (NOAA) Fisheries Service. 2015. Federal Register: Notices-notice concerning plan to amend the herring management plan so that catch will account for herring's role in the ecosystem, Vol. 80, No. 38 [online]: Available from http://www .greateratlantic.fisheries.noaa.gov/regs/2015/February/15heramend8noiscopingfr.pdf; http://s3 .amazonaws.com/nefmc.org/150109-Draft-Amendment-8-Scoping-Doc-for-AP-Committee.pdf [accessed 15 September 2015].

National Oceanic and Atmospheric Administration (NOAA) fishwatch. 2014a [online]: Available from http://www.fishwatch.gov/profiles/acadian-redfish [accessed 15 September 2015].

National Oceanic and Atmospheric Administration (NOAA) fishwatch. 2014b [online]: Available from http://www.fishwatch.gov/profiles/atlantic-herring [accessed 15 September 2015].

National Oceanic and Atmospheric Administration (NOAA) fishwatch. 2014c [online]: Available from http://www.fishwatch.gov/profiles/haddock [accessed 15 September 2015].

New England Fishery Management Council (NEFMC). 2010. Proposed Atlantic herring specifications for the 2010-2012 Fishing Years [online]: Available from https://www.greateratlantic.fisheries.noaa. gov/nero/regs/frdoc/10/10Herring2010SpecsEA.pdf [accessed 15 September 2015].

Nye JA, Link JS, Hare JA, and Overholtz WJ. 2009. Changing spatial distribution of fish stocks in relation to climate and population size on the Northeast United States continental shelf. Marine Ecology: Progress Series, 393: 111-129. doi:10.3354/meps08220.

Oro D, Martínez-Abraín A, Villuendas E, Sarzo B, Mínguez E, Carda J, and Genovart M. 2011. Lessons from a failed translocation program with a seabird species: Determinants of success and conservation value. Biological Conservation, 144(2): 851-858. doi:10.1016/j.biocon.2010 .11 .018 .

Overholtz WJ. 2002. The Gulf of Maine-Georges Bank Atlantic herring (Clupea harengus): Spatial pattern analysis of the collapse and recovery of a large marine fish complex. Fisheries Research, 57(3): 237-254. doi:10.1016/S0165-7836(01)00359-9.

Overholtz WJ, Jacobson LD, and Link JS. 2008. An ecosystem approach for assessment advice and biological reference points for the Gulf of Maine-Georges Bank Atlantic herring complex. North American Journal of Fisheries Management, 28: 247-257. doi:10.1577/M06-267.1.

Pershing AJ, Greene CH, Jossi JW, O’Brien L, Brodziak JKT, and Bailey B. 2005. Interdecadal variability in the Gulf of Maine zooplankton community, with potential impacts on fish recruitment. ICES Journal of Marine Science, 62: 1511-1523. doi:10.1016/j.icesjms.2005.04.025. 
Pershing AJ, Alexander MA, Hernandez CM, Kerr LA, Bris AL, Mills KE, Nye JA, Record NR, Scannell HA, Scott JD, Sherwood GD, and Thomas AC. 2015. Slow adaptation in the face of rapid warming leads to collapse of the Gulf of Maine cod fishery. Science, 350(6262): 809-812. PMID:26516197. doi:10.1126/science.aac9819.

Read AJ, and Brownstein CR. 2003. Considering other consumers: fisheries, predators and Atlantic herring in the Gulf of Maine. Conservation Ecology, 7(1): 2 [online]. Available from http://www consecol.org/vol7/iss1/art2.

Rose GA. 2005. On distributional responses of North Atlantic fish to climate change. ICES Journal of Marine Science, 62(7): 1360-1374. doi:10.1016/j.icesjms.2005.05.007.

Skern-Mauritzen M, Ottersen G, Handegaard NO, Huse G, Dingsør GE, Stenseth NC, and Kjesbu OS. 2015. Ecosystem approaches are rarely included in tactical fisheries management. Fish and Fisheries, 17(1): 165-175. doi:10.1111/faf.12111.

Smith LA, Link JS, Cadrin SX, and Palka DL. 2015. Consumption by marine mammals on the Northeast U.S. continental shelf. Ecological Applications, 25(2): 373-389. PMID:26263661. doi:10.1890/13-1656.1.

Spencer SM. 2012. Diving behavior and identification of sex of breeding Atlantic puffins (Fratercula arctica), and nest-site characteristics of alcids on Petit Manan Island, Maine. M.Sc. thesis, University of Massachusetts, Amherst. $75 \mathrm{p}$.

Tyrell MC, Link JS, and Moustahfid H. 2011. The importance of including predation in fish population models: Implications for biological reference points. Fisheries Research, 108: 1-8. doi:10.1016/j. fishres.2010.12.025.

Travis J, Coleman FC, Auster PJ, Cury PM, Estes JA, Orensanz J, Peterson CH, Power ME, Steneck RS, and Wootton JT. 2014. Integrating the invisible fabric of nature into fisheries management. Proceedings of the National Academy of Sciences, 111(2): 581-584. PMID:24367087. doi:10.1073/ pnas. 1305853111.

Townsend DW, Rebuck ND, Thomas MA, Karp-Boss L, and Gettings RM. 2010. A changing nutrient regime in the Gulf of Maine. Continental Shelf Research, 30(7): 820-832. doi:10.1016/j.csr.2010.01 .019 .

Wanless S, Harris MP, Redman P, and Speakman JR. 2005. Low energy values of fish as a probable cause of a major seabird breeding failure in the North Sea. Marine Ecology: Progress Series, 294: 1-8. doi:10.3354/meps294001. 